$\Phi=$

\title{
Therapeutic management of Argulosis in Carp ponds, Andhra Pradesh, India
}

\author{
Kurva Raghu Ramudu ${ }^{1 *}$, B. Chamundeswari Devi ${ }^{2}$, Bokka Pavan Kumar ${ }^{3}$ \\ ${ }^{1}$ Scientist, Fisheries Research Station, Sri Venkateswara Veterinary University (SVVU), Kakinada-533 001, A.P., India \\ ${ }^{2}$ Principal Scientist \& Head, Fisheries Research Station, SVVU, Kakinada-533 00, A.P., India \\ ${ }^{3}$ Fisheries Development Officer, Uppada, A.P., India \\ *Corresponding author E-mail:ram.raghu77@gmail.com
}

\begin{abstract}
Background: The genus Argulus sp. belongs to class Crustacea (Branchiura), which is commonly called as fish louse. These are common parasites on freshwater fish like carps (Both Indian Major Carps and Exotic Carps).

Objectives:The aim of present study is to determine the prevalence, severity of infestation and control measures of Argulosis in Carp ponds.

Results: In the present work about 233 fishes were examined, 53 were found infected $(22.74 \%)$ and severity of infestation varied from 0.5 to 2 . Argulus sp. were found and infected various organs such as dorsal fins, anal fin, pectoral fins, pelvic fins and head region of carps.

Conclusion: The present study also, brings about the conclusion that the prevalence rate of Argulus sp. is high in Labeo rohita followed by Cirrhinus mrigala and Catla catla respectively.
\end{abstract}

Keywords: Carps; Argulosis; Therapy.

\section{Introduction}

Fish culture occupies is very important place in the socio-economic development of the country. It is an important part of Indian economy as it provides employment opportunities, source of nutritional food and foreign exchange earnings. Disease is one of the major constraints to intensification of aquaculture, and may eventually become a limiting factor to the economic success of the industry. High stocking densities of fry and fingerlings during nursery operation generally increases stress and is turns to susceptibility to infectious diseases. Thousands of fish parasite species are already known and many more remain to be discovered. However, very few are seriously harmful to the cultivable fish. The presence of dense populations of fish kept in particular environmental conditions may favor certain parasites necessary to cause harm to a fish and it is varies considerably with the species, size of the host and weather condition.

Parasitic diseases are usually encountered more frequently than microbial diseases in intensive Carp culture systems. This can become particularly severe in culture ponds when fish are kept under crowded conditions. Among the parasitic diseases, Argulosis ranks first in the Carp culture. Argulosis has become a major pest problem to the carp culture. In the present study, 'splashing behavior' has been observed and considered as one of the dependable tools of observations for identification, various management interventions to control Argulosis.

\section{Materials and methods}

The samples were collected from Balabadrapuram at fish farms, Andhra Pradesh, India on a regular basis once in every month. In each sampling minimum of 60 fishes (comprising 20 to 30 of each Catla catla, Labeo rohita, Cirrhinus mrigala) were collected in live condition. The fishes were brought to the laboratory in live condition with water filled buckets and the total length, body weight of fishes were taken. The methods for collection and preservation of the samples for parasitic examination were followed as described by Soota (1980).

The parasitic frequency index (PFI) was calculated by using following formula.

F1. Prevalence $(\%)=\frac{\text { Total number of infected fishes }}{\text { Total number of fish host examined }} \times 100$

The frequency index were further classified into rare $(0.1-9.9 \%)$, occasional (10-29.9\%), common $(30-69.9 \%)$ and abundant (70$100 \%)$ as per Srivastava (1980).

\subsection{Determination of severity of infection/ infestation}

In order to assigning numerical qualitative value to severity grade of infections/infestation, surface infestation and disease syndrome severity, the generalize scheme by Lightner (1993) and Ramudu and Dash (2013) was followed. 


\subsection{Case History, Clinical Examination and discussion}

The date and site of collection were recorded and the fishes were examined for parasites within 12 hours. External symptoms and health conditions of each specimen were recorded. The gills, fins, scales and operculum were removed with least damage and placed on separate petri-dishes containing saline water and examined. The gills and body surface were checked thoroughly for any parasites. The dorsal, pectoral, pelvic, anal, and caudal fins were cut and placed in separate petri-dishes. Each fin was thoroughly examined for parasites.

Gross observation revealed that Argulus sp. were found, sucker like mouth and small hooks like structures on their legs, both of which they use to attach fish and feed (Fig.1 \& 2). First they insert a long sting- like structure called stylet and inject enzymes into the skin and flesh of the fish to break down these tissues to make them easier for parasites to consume. Aggressive attachment and feeding behavior can cause great irritation to the fish which can be cause rubbing their bodies against any hard surface or objects and flick or flash of caudal fin to try to get rid of the parasite.

Very heavily infected fishes were found and these were lethargic and spend less time for feeding than lightly infected or uninfected individuals which is supported by Wendelaar Bonga (1997), Walk- er et al., (2004). In this condition the adult fish lice (Fig.3 \& 4) were observed all over the skin and fins of the fish and in the water column. Few signs of disease were observed such as localized inflammation and damage at the affected site may lead to secondary infections, this observation is similar with the results of Noga (2010). Secondary pathogens, such as the bacteria Aeromonas and the water mold Saprolegnia, are often seen concurrently with $A r$ gulus sp. Infestations.

Clinical examination revealed that pinpoint hemorrhages, anemia, fin and scale loss, increased mucus production, lethargy, erratic swimming, reduced feeding, hanging at the surface (avoiding swimming into the water column) and poor body condition were also observed. The current above symptoms are corroborated and agree with results of Hoffman (1999). Fish may "flash" or rub against surfaces in an attempt to relieve irritation or to remove the parasites.

Prevalence (PFI \%) and severity of infection of Argulus sp. were also recorded during the period between July 2014 and September 2014 and shown in the following Table-1. Prevalence rate and severity of infection of Argulosis is high in Labeo rohita followed by Cirrhinus mrigala and Catla catla respectively.

Table 1: Prevalence (PFI \%) and Severity of Infectionof Argulus Sp. During the Period between July 2014 and September 2014.

\begin{tabular}{|c|c|c|c|c|c|c|}
\hline Months & Fishes & $\begin{array}{l}\text { Total no. of Fish } \\
\text { investigated }\end{array}$ & $\begin{array}{l}\text { No. of } \\
\text { Infested } \\
\text { fishes }\end{array}$ & $\begin{array}{l}\text { PFI } \\
(\%)\end{array}$ & Site of infestation & $\begin{array}{l}\text { Severity of infes- } \\
\text { tation }\end{array}$ \\
\hline \multirow{3}{*}{ July } & Catla catla & 27 & 9 & 33.3 & Dorsal, anal fin & 0.5 \\
\hline & Labeo rohita & 25 & 18 & 72.0 & \multirow{2}{*}{$\begin{array}{l}\text { Dorsal fin, } \\
\text { Caudal fin and on the body } \\
\text { Pectoral, pelvic fins }\end{array}$} & 1 \\
\hline & Cirrhinus mrigala & 29 & 12 & 41.3 & & 0.5 \\
\hline \multirow{3}{*}{ August } & Catla catla & 25 & 2 & 8.0 & On the body & 0.5 \\
\hline & Labeo rohita & 30 & 5 & 16.6 & Caudal fin, Tail fin & \multirow{2}{*}{$\begin{array}{l}2 \\
0.5\end{array}$} \\
\hline & Cirrhinus mrigala & 20 & 3 & 15.0 & Caudal fin & \\
\hline \multirow{3}{*}{ September } & Catla catla & 27 & 1 & 3.7 & Head region & 0.5 \\
\hline & Labeo rohita & 22 & 2 & 9.0 & Pelvic fin, Dorsal fin, Caudal fin & 1 \\
\hline & Cirrhinus mrigala & 28 & 1 & 3.5 & On the body & 0.5 \\
\hline Total Prevalence $(\%)$ & & 233 & 53 & 22.7 & --- & --- \\
\hline
\end{tabular}

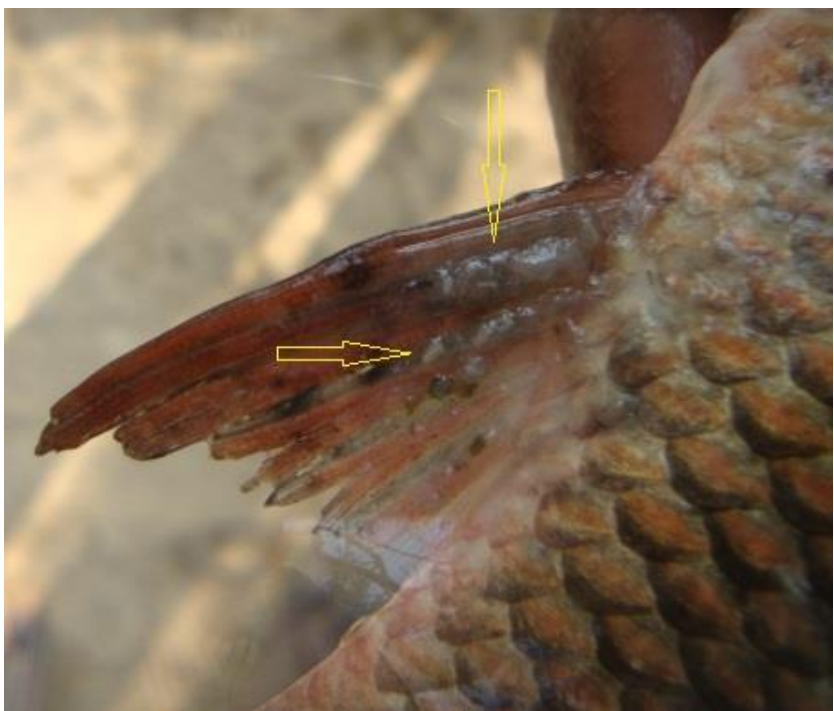

Fig. 1: Argulus sp. Attached (Yellow Arrow) in the Pectoral Fin of Labeorohita.

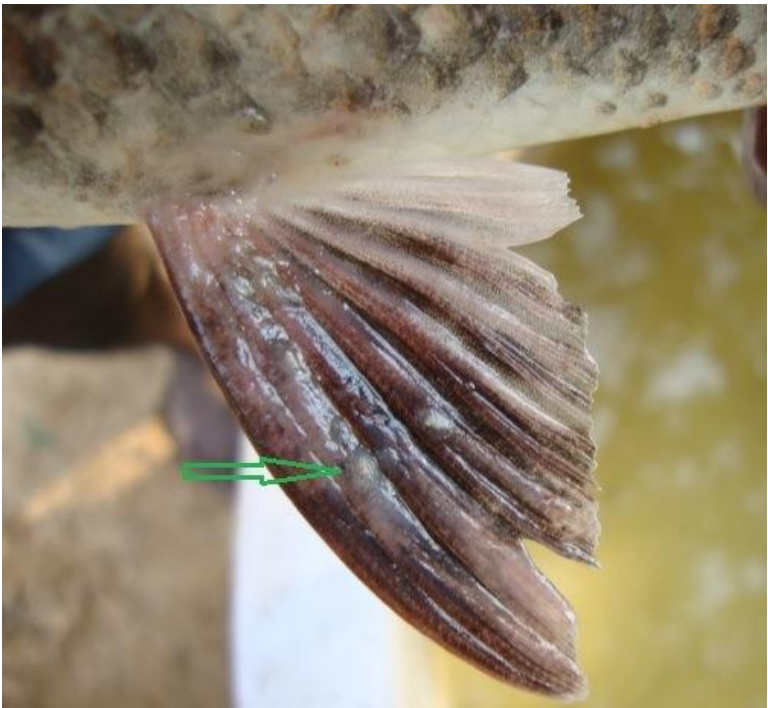

Fig. 2: Argulus sp. Found (Green Arrow) in the Dorsal Fin of Cirrhinus mrigala 


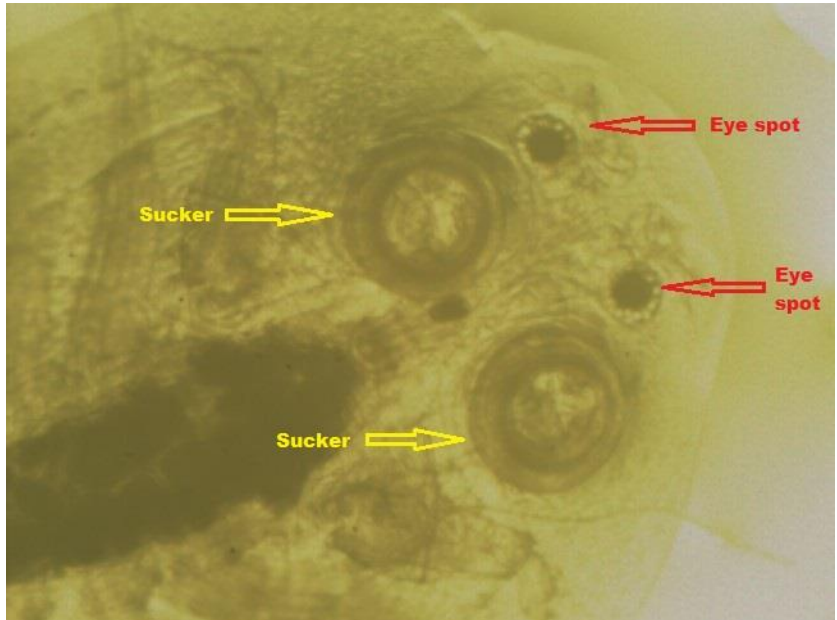

Fig. 3: Argulus Sp. with Distinct Sucker (Yellow Arrow) and Eye Spots (Red Arrow) Isolated from Anterior Part of Labeo rohita (Wet Mount,40x).

\section{Treatment and discussion}

Fishes were treated with AverTin (Ivermectin powder BP1\%W/W) along with feed @ 200-250gm/1 ton of feed or $10 \mathrm{gm}$ for one ton of livefishes for four days and repeat after every three months depending on the condition of infestation. The fishes were responded to treatment and showed improvement after one week. Application procedure: mix thoroughly 200-250 gms of Aver Tin powder in $50 \mathrm{~kg}$ of feed to make a premix. Then remix the premix thoroughly with one ton of feed before feeding.

Bio spot: It is also used some of the farmers @ half liter per hector as a first dose and second dose need to be given after one month. Several medications have historically been used for treatment of Argulosis. There are currently no FDA-approved drugs for the treatment and control of Argulus. Prolonged immersion of an organophosphate pesticide, such as trichlorfon and dichlorfon is an effective treatment when dosed at $0.25-0.50 \mathrm{mg} / \mathrm{l}$ active ingredient, once a week for 4 treatments but which acts by disrupting the nervous system. Diflubenzuron and Tiflubenzuron is another pesticide, which effectively kills both adult and larval stages, but it is a restricted-use pesticide, and applicators must follow label instructions.

Potassium permanganate $(10 \mathrm{mg} / \mathrm{L}$ for 30 minutes, or $1.3 \mathrm{mg} / \mathrm{L}$ applied twice over 3 days) has been shown to be effective in killing the juvenile and adult stages of freshwater parasitic species in several studies. Increased salt concentration does not appear to be effective for the control of Argulus sp. in freshwater.

\section{Conclusion}

The present study brings about the conclusion infestation of Argulus sp. in Indian Major Carps was diagnosed and can be successfully treated with the latest drugs. This is practiced by most of the farmers in the field for control of Argulosis. The complete recovery was observed within three months of treatment. Still regular checkup of pond for every day and depending on the condition of infestation treatment is required.

Argulus sp. infestations are not uncommon in wild or carps. Because infections can rapidly escalate, causing disease and mortalities, so, management and treatment are recommended as soon as Argulusis identified in carps. While several effective treatments are possible, availability, legalities, logistics and fish species' sensitivities should be considered. The best way to avoid an Argulus infestation is through good biosecurity, including screening and quarantine of incoming fish, and continuous observation of all fish.

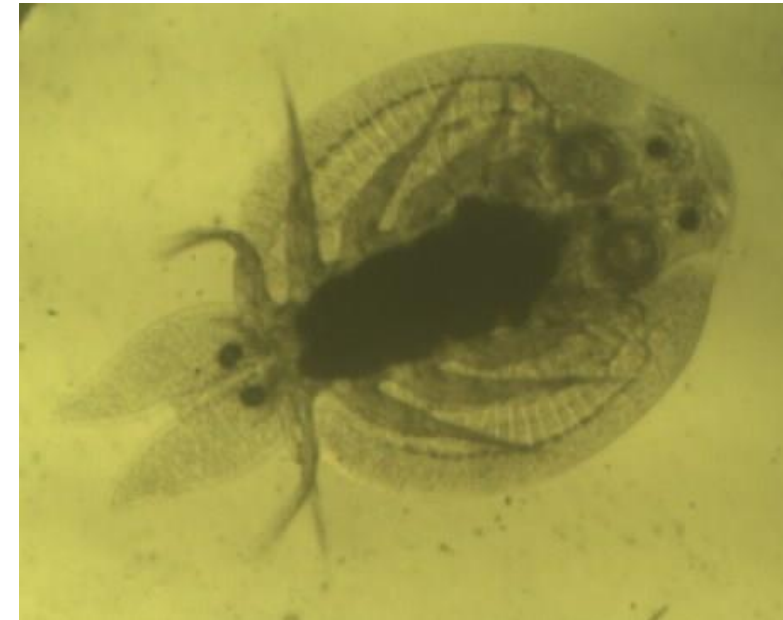

Fig. 4: Adult Argulus Sp. with Distinct Organelle Isolated from the Body of Catla catla (Wet Mount,40x).

\section{References}

[1] Hoffman GL. Parasites of North American freshwater fishes. 1999; Cornell University Press, Ithaca, NY.

[2] Lightner DV. Diseases of cultured penaeid shrimp. In: J.P. McVey (ed.), Handbook of Mariculture, Crustacean Aquaculture.Second Edition, CRC Press, Boca Raton, FL.1993; 1: 289-320.

[3] NogaEJ.Fish disease diagnosis and treatment, 2nd ed., Mosbyyearbook, Inc. watsworth publishing Co., USA.2010; 366.http://dx.doi.org/10.1002/9781118786758.

[4] Ramudu KR, Dash G. Prevalence of Monogenean Parasites on Indian Major Carps in Bheries of West Bengal, International Journal of Chemical and Biochemical Sciences, 2013; 4:13-21.

[5] Soota TD. Collection and preservation of trematodes and cestodes. Proc.Workshop Tech. Parasitol. Zool. Surv. India.1980; 27-29.

[6] Srivastava CB. Estimation of helminthic infections.Proc. Workshop Tech. Parasitol. Zool. Surv. India.1980; 29-31.

[7] Walker PD, Flik G, WendelaarBonga SE. The biology of parasites from the genus Argulusand a review of the interactions with its host. Symp.Soc. Exp. Biol.2004; 55: 107-129.

[8] Wendelaar BongaS.E.The stress response in fish. Physiol. Rev. 1997;77: 591-625. 